\title{
The Impact of Proactive Personality on Job Performance through Job Crafting: The Case of Vietcombank in Ho Chi Minh City
}

\author{
Phan Quan Viet, PhD \\ Faculty Commerce and Business Administration \\ Van Lang University, Viet Nam \\ Truong Anh Tuan, MBA \\ Faculty Commerce and Business Administration \\ Van Lang University, Viet Nam
}

Received: July 6, 2018 Accepted: July 20, 2018 Published: August 17, 2018

doi:10.5296/ber.v8i3.13513ＵRL: https://doi.org/10.5296/ber.v8i3.13513

\begin{abstract}
This study was conducted to measure the impact of the proactive personality to job job performance through job crafting of employees at Vietcombank in Ho Chi Minh City. The study conducted a survey of 182 employees at Vietcombank transaction offices in Ho Chi Minh City. Research data was analyzed by techniques: descriptive statistics, scale reliability, EFA, CFA, and SEM. The results of the factor analysis show that the proactive personality scale consists of one component; the job crafting scale consists of three components: increasing structural job resources, increasing social job resources and increasing challenging job requirement; the job performance scale consists of one component. The results of the SEM analysis showed that the proactive personality and job crafting had a positive impact on the job performance of employees. From the results of the analysis, the study suggests some solutions that need to be focused on to motivate the proactive personality and the job crafting in order to improve the job performance of the employees at Vietcombank in Ho Chi Minh
\end{abstract} City.

Keywords: Proactive personality, Job crafting, Job performance, CFA, SEM

\section{Introduction}

2017 is considered as essential time for Vietcombank to take advantage of new opportunities 
in integration. In which, the training and development of high quality human resources, meeting international standards and rules, contributing to improve the quality, efficiency of banking operations in the context of integration and economic globalization are one of the top priority targets. Therefore, the employees' proactive personality, through job crafting, will contribute significantly to enhance the performance of Vietcombank's employees.

According to Buss (1987), the proactive personality does not passively receive the pressures from the surrounding environment. Instead, they actively influence their environment. According to Bateman and Crant (1993), the proactive personality is defined as a relatively stable trend that affects the change of the surrounding environment, which refers to a flexible tendency to actively adapt to different situations. A person who has the proactive personality always identifies opportunities, actions, and persistence until he or she achieves a significant change (Crant, 1995). Studies have established a relationship between proactive personality and job performance (Crant, 1995), job effectiveness (Seibert et al., 1999), leadership style (Crant and Bateman, 2000; Deluga, 1998), organizational improvement (Parker, 1998), team effectiveness (Kirkman and Rosen, 1999), business relations (Becherer and Maurer, 1999; Crant, 1996).

Job Crafting is a process of change made by an employee to change his or her duty and limit his or her job (Wrzesniewski and Dutton, 2001). According to Berg et al. (2008), job crafting is a process that can be expressed at the material and /or cognitive level. Material level refers to changes made by an employee within the framework or scope of work, while the level of awareness refers to changes in employee's perceptions of their work (Bakker et al., 2012a).

According to Saetang et al. (2010), job performance plays an important role in determining the working efficiency of an organization, its success or failure is based on job performance of each individual. Therefore, managers need to create a professional working environment, motivation and a solid foundation to meet the needs of the employees so that they can maximize their self-efficacy, achieve efficiency as desired, contribute to the success of the organization.

The research question is: How does the proactive personality affect job performance through job crafting? The answer to this question is to provide some management implications for Vietcombank's managers so as to encourage the employee's proactive personality, job crafting and improve job performance.

\section{Theoretical Basis and Research Model}

Bakker et al. (2012b) considers the role of the proactive personality in predicting job crafting, job cohesion, and job performance. Based on the reasearch of the proactive personality and the job demands-resources model (JD-R), the researches hypothesize that employees with proactive personality will be more likely for their own job crafting, increases job cohesion and job performance. Data were collected on 95 pairs of employees $(\mathrm{N}=190)$ working in different organizations. The results of the structural equation model analyzed strongly support for model and hypothesis. Employees characterized by proactive personality are more likely for their own job crafting (increasing the social and structural job resources and increasing 
their job challenges); after that, the job crafting has a positive impact on job cohesion (morale, dedication and perceptions) and job performance from colleagues' assessments. These results indicate that, by extension, the employee with the proactive personality will actively adjust their working environment, they are always successful in cohension with the organization and perform the job well.

Crant's theory on the proactive personality (2000), the proactive personality will make the convenient condition and the opportunity for the employee in his or her job. Tims and Bakker (2010) has argued that the employees with the proactive personality always strive to fit the environment based on their demands and abilities. They shape the working environment according to job demands and resources to better match their demands and abilities. Based on these theories, research suggests that employees with the proactive personality are more likely to ask for help and feedback (social job resources), and actively enrich their working environment, for example, ask for autonomy, create many skills, and provide training (structural job resources). In addition, research suggests that the employees with the proactive personality are more likely to look for challenges, for example they require more work when they feel lack of encouragement. Therefore, the study of the first hypothesis is as follows:

Hypothesis 1 (H1): The proactive personality has a positive effect on job crafting (increasing structural job resources, increasing social job resources, increasing job challenges).

The study by Tims et al. (2012) collected data for 95 pairs of employees, each of whom performed two questionnaires. First, each employee would self-evaluate and then evaluate their colleagues. Research result indicated that employees tended to restructure their job (increasing structural job resources, increasing social job resources, and increasing job challenges) had better job performance than the rest of employees.

The studies on job crafting of Wrzesniewski and Dutton, (2001) and Berg et al., (2010) predicted that the employee optimized work requirement to be challenged, and employees increase structural job resources and social job resources better than those who did not increase their job requirements and resources. Lyons (2008) confirmed that all cases of job crafting had a positive impact on the organization. Therefore, the study of the second hypothesis is as follows:

\section{Hypothesis 2 (H2): Job crafting has a positive effect on job performance.}

Thompson's study (2005) found that individuals with the proactive personality always performed well because of their personal initiative and involvement in building network. The research by Greguras and Diefendorff (2010) showed a positive, direct relationship between the proactive personality and job performance.

Daniels' study (2006) indicated that the general personality was an important predictor of job performance in an organization. The results of this study show the indirect effect of job crafting on job performance after control of the proactive factor. Further studies may test the hypothesis by using a stronger design, such as combining the questionnaire of characteristics of the proactive personality with the employee's daily work diary (Ohly et al., 2010). Thus, the study of the third hypothesis is as follows: 
Hypothesis 3 (H3): The proactive personality has a positive effect on job performance.

Recommended research model:

Crant's study (1995) consisted of 131 real estate employees found that employee's the proactive personality influenced strongly job performance (number of houses sold, commission income) after control of the experience variable and other personality variables.

Thompson's study (2005) used a structural equation model to show the relationship between the proactive personality and job performance through intermediary variables was building networks and employee's creativity.

Baba et al.'s study (2009) analyzed the relationships between the proactive personality and behavioral outcomes, including organizational citizenship behavior (OCB) and performance, concurrently the research analyzed interactions between emotional exhaustion and cognitive safety. Research shows that the proactive personality predicted positively organizational citizen behavior and job performance. Emotional exhaustion and cognitive safety abstained in different direction between the proactive personality and job performance.

Bakker et al. (2012) used a structural equation model to show that employees with the proactive personality were always successful in job crafting, increasing job cohesion and job performance. This study showed that the proactive personality was an important factor influencing job performance.

Combining the above-mentioned basis, studying and proposing the following research model:

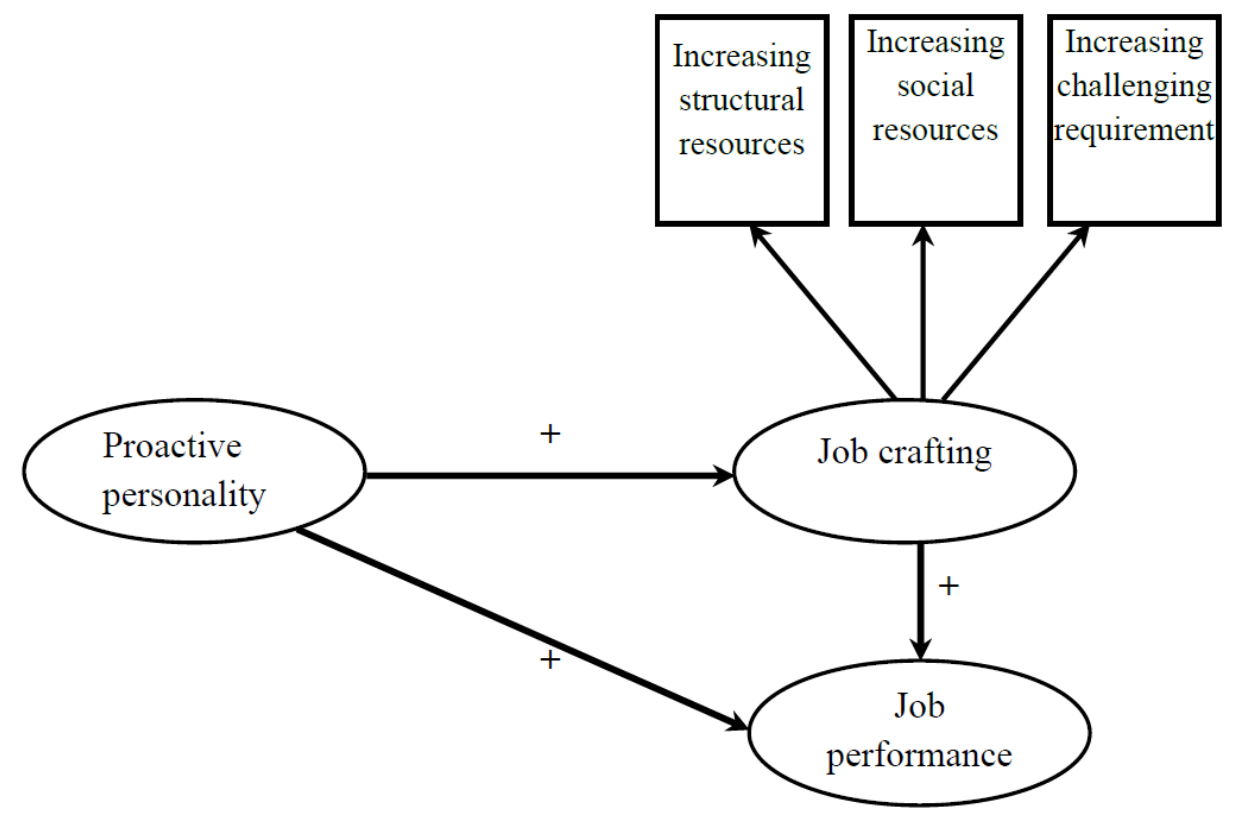

Figure 1. Recommended research model

\section{Research Method and Research Data}

Research uses qualitative and quantitative research method. The research data is analyzed by 
the techniques: descriptive statistics, scale reliability test, Exploratory Factor Analysis (EFA), Confirmatory Factor Analysis (CFA) and Structural Equation Model (SEM). The scale is designed according to Likert 5 levels and is adjusted based on the original scales: Seibert et al.'s proactive personality scale (1999), consists of 11 observation variables; Tims et al.'s job crafting scale (2012), consists of of 3 components with 17 observation variables; and Williams and Anderson's job performance scale (1991), consists of 7 observation variables.

The sample was selected by the convenient method. The study conducted the survey of full time employees at Vietcombank's transaction offices in Ho Chi Minh City. The data used in the study were collected from live interviews and questionnaires sent via e-mail. The total number of questionnaires distributed was 225, collected 202. The result was that 182 questionnaires were used to be research data, accounting for $90.1 \%$ compared to the collected questionnaires.

\section{Research Result}

\subsection{Sample Statistic by Characteristics}

In term of gender: 103 male and 79 female, accounting for $56.6 \%$ and $43.4 \%$, respectively. In term of age: under 30 years old accounting for $37.4 \%$, from 30 to 40 years old accounting for $46.1 \%$ and over 40 years old accounting for $16.5 \%$. In term of job position: staff / specialist accounting for $63.2 \%$, group leader/team leader accounting for $14.3 \%$ and Manager/Vice Manager accounting for $22.5 \%$. In term of education level: high school education/ intermediate school education accounting for $4.6 \%$, college education accounting for $17.0 \%$, university education accounting for $64.3 \%$ and postgraduate accounting for $14.1 \%$. In term of seniority: less than 5 years accounting for $30.8 \%$, from 5 to 10 years accounting for $48.4 \%$ and over 10 years accounting for $20.8 \%$. In term of income accounting for less than 5 million accounting for $11.0 \%$, from 5 to 10 million accounting for $45.1 \%$ and over 10 million accounting for $43.9 \%$.

\subsection{Cronbach's Alpha Analysis and Exploratory Factor Analysis}

Proactive personality scale: Cronbach's alpha test results showed that the proactive personality scale's observational variables had a variable correlation coefficient greater than 0.3 and had a Cronbach's alpha reliability coefficient of $0.898>0.6$. Thus, these variables are used in the next EFA analysis.

The results of the first EFA analysis for the proactive personality scale, KMO coefficient result is $0.901>0.5$, qualified, but the CD8 variable with the factor loading in both factors of 0.667 and 0.504 , respectively, the difference between two factor loading is $0.163<0.3$, so rejects the CD8 variable. The result of the second factor analysis of the proactive personality scale showed that one factor was extracted and no observational variables were rejected. The coefficient of KMO is 0.899 , the significance level is $0.000<0.05$, the Corrected Item-Total Correlation is $50.839 \%$ and the factor loading of the observation variables is greater than 0.5 . This result shows that the factor analysis is consistent with the survey data.

Job crafting scale: The result showed that the components of the job crafting scale had a 
Cronbach's alpha coefficient greater than 0.6. However, the Corrected Item-Total Correlation of the CT5 observational variable is $0.021<0.3$, so the CT5 variable is rejected. After Cronbach's alpha testing, the rest of the job crafting scale was 16 observational variables with three components, with the Cronbach's alpha coefficient of each component: increasing structural job resources is 0.774 , increasing social job resources is 0.842 and increasing challenging job requirement is 0.769 .

The results of the first EFA analysis for the structural job scale with a KMO coefficient of 0.795 are appropriate. However, the CT4 variable has factor loading of two factors and the factor loading difference is $0.25<0.3$ should be rejected. Concurrently, TT2 variable has a factor loading of 0.378 , which is also rejected. The results of the second EFA analysis revealed that 14 observational variables meeting the requirements of the job crafting scale were extracted in three factors: increasing structural job resources, increasing challenging job requirements, and increasing social job requirements. The KMO coefficient is 0.783 , the significance level is $0.000<0.05$, the total variance explained is $58.873 \%$ and the factor loading of the observational variables is greater than 0.5 . This result showed that the factor analysis is consistent with the survey data.

Job performance scale: The result of the analysis showed that the observational variables of the job performance scale had the Corrected Item-Total Correlation greater than 0.3 and Cronbach's Alpha reliability coefficient was $0.937>0.6$. Thus, these observational variables are used in the next EFA analysis.

The result of the factor analysis on the job performance scale showed that one factor was extracted and no observational variables were rejected. The KMO coefficient of 0.873 is appropriate, the significance level is $0.000<0.05$, the total variance explained is $69.660 \%$ and the factor loading of the observational variables is greater than 0.5 . This result shows that the factor analysis is consistent with the survey data.

\subsection{Confirmatory Factor Analysis (CFA)}

Theoretical factors are built and hypothesized to be the unidimensional scale and verified through exploratory factor analysis. Thus, in the confirmatory factor analysis, the study examines the critical model for convergence value, discriminative value and model compatibility with market data. It means to consider the model when the reseraching variables are independently related, if the critical model is compatible with the market data, the component factor models will be also compatible with the market data. Critical models were built after two EFA exploratory factor analyses for all factors. The study rejected 8 observational variables with no convergence value and had a factor loading less than 0.5 at the first EFA analysis: CD2, CD5, CD10, CD11, CT1, TT4, XH4, KQ1. Principal components analysis used is Principal Axis Factoring with Promax non-perpendicular rotation (Table 1). 
Table 1. Results of the second EFA analysis for critical model

\begin{tabular}{|c|c|c|c|c|c|c|}
\hline \multirow{2}{*}{ Encode } & \multirow{2}{*}{ Observational variable } & \multicolumn{5}{|c|}{ Factor } \\
\hline & & 1 & 2 & 3 & 4 & 5 \\
\hline KQ8 & Have you completed the assigned tasks on time? & 1.022 & & & & \\
\hline KQ5 & $\begin{array}{l}\text { Do you often participate in activities that directly affect your } \\
\text { job performance assesment? }\end{array}$ & 0.997 & & & & \\
\hline KQ7 & Do you often fail to perform important tasks? & 0.791 & & & & \\
\hline KQ6 & $\begin{array}{l}\text { Do you often neglect the aspects of the job you are required } \\
\text { to do? }\end{array}$ & 0.780 & & & & \\
\hline KQ4 & Do you meet the main requirements of the job? & 0.755 & & & & \\
\hline KQ3 & Do you perform the tasks expected of you? & 0.713 & & & & \\
\hline KQ2 & $\begin{array}{l}\text { Do you fulfill the responsibilities specified in the job } \\
\text { description? }\end{array}$ & 0.554 & & & & \\
\hline CD3 & $\begin{array}{l}\text { Do you find nothing more interesting to see your ideas come } \\
\text { true }\end{array}$ & & 0.802 & & & \\
\hline CD4 & If you find something you dislike, you will change it & & 0.755 & & & \\
\hline CD9 & $\begin{array}{l}\text { You can recognize a good opportunity for a long time before } \\
\text { others can }\end{array}$ & & 0.739 & & & \\
\hline CD7 & You always find better ways to do the job & & 0.646 & & & \\
\hline CD1 & You always aim for new ways to improve your life & & 0.636 & & & \\
\hline CD6 & You are good at identifying opportunities & & 0.592 & & & \\
\hline XH2 & You asked if your supervisor was satisfied with your job & & & 0.767 & & \\
\hline XH3 & You take your supervisor as a model for inspiring you & & & 0.723 & & \\
\hline XH1 & You recommend the instructor for training & & & 0.677 & & \\
\hline XH5 & You consult your colleagues about the advice & & & 0.619 & & \\
\hline CT3 & You assure that you have done all your best to work & & & & 0.678 & \\
\hline CT7 & You always acquire opinions of leaders to perform a job well & & & & 0.654 & \\
\hline $\mathrm{CT} 2$ & You try to learn new experiences from work & & & & 0.653 & \\
\hline CT6 & $\begin{array}{l}\text { You learn from your colleagues' experience to perform a } \\
\text { good job }\end{array}$ & & & & 0.613 & \\
\hline TT3 & $\begin{array}{l}\text { When there is no more work to do, you see it as an } \\
\text { opportunity to start a new project }\end{array}$ & & & & & 0.716 \\
\hline TT1 & $\begin{array}{l}\text { When an interesting project is launched for implementation, } \\
\text { you pioneeringly propose to be a member of that project }\end{array}$ & & & & & 0.663 \\
\hline TT5 & $\begin{array}{l}\text { You try to make your job more challenging by } \\
\text { understanding the relationships within the work }\end{array}$ & & & & & 0.562 \\
\hline
\end{tabular}

After running EFA for the critical model, the study conducted CFA analysis for the components of the model. The results of CFA analysis are shown in Figure 2. 


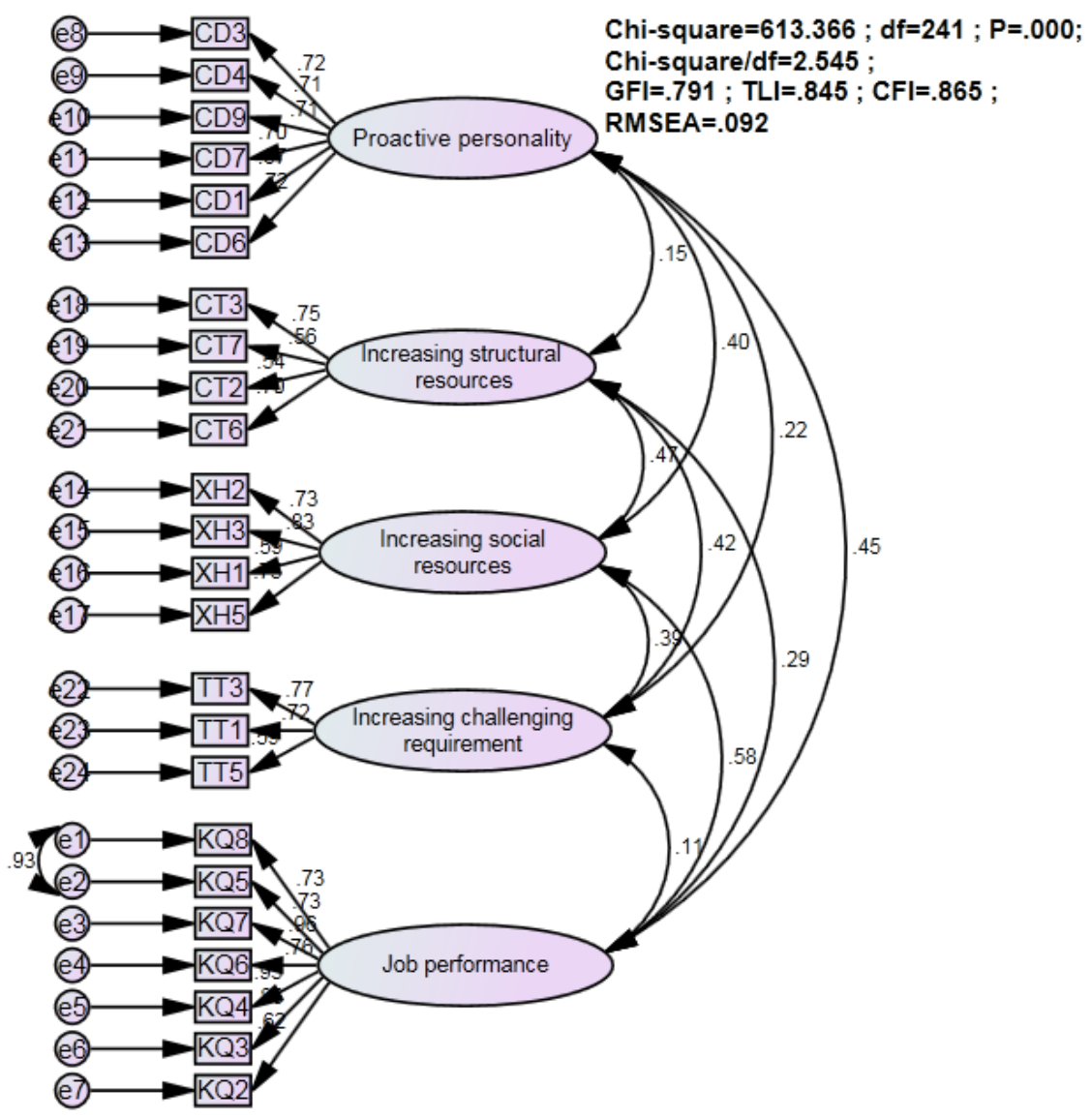

Figure 2. CFA analysis for critical model

The results of the critical model analysis after adjusting the covariance relationship between the errors of the observational variables through the Modification Indices (MI) (e1 and e2) show that Chi-square/df $=2.545$ less than $3, \mathrm{p}$-value $=0.000$ with statistical significance, TLI $=0.845, \mathrm{CFI}=0.865$ is very close to $0.9, \mathrm{GFI}=0.791$ is close to $0.8, \mathrm{RMSEA}=0.092$ is close to 0.08 , standardized weighting factor of the observtional variables with latent variables are greater than 0.5 . It demonstrates that the model is consistent with the market data, the research concepts taken into consideration to reach convergence value (Figure 2).

Results of covariance verification between concepts with estimated coefficient and p-value had a statistical significance ( $\mathrm{p}$-value $<0.1$ ). Only the link between challenging job requirement factor and job performance are weak because the p-value is $0.229>0.1$. Thus, most of the variables studied reach a distinguishable value (Table 2).

Table 2. Results of covariance estimate of variables

\begin{tabular}{|c|c|c|c|c|c|c|}
\hline \multicolumn{3}{|c|}{ Relationship between variables } & Estimate & S.E. & C.R. & P-value \\
\hline Proactive personality & $\langle-->$ & Social job resources & 0.189 & 0.048 & 3.969 & $* * *$ \\
\hline Proactive personality & $\langle-->$ & Structural job resources & 0.081 & 0.050 & 1.636 & 0.102 \\
\hline Proactive personality & $\langle-->$ & Challenging job requirement & 0.103 & 0.045 & 2.312 & 0.021 \\
\hline Social job resources & $\langle-->$ & Challenging job requirement & 0.172 & 0.046 & 3.718 & $* * *$ \\
\hline
\end{tabular}




\section{Macrothink}

Business and Economic Research

ISSN 2162-4860

2018, Vol. 8, No. 3

\begin{tabular}{|l|c|l|c|c|c|c|}
\hline Structural job resources & $\langle-->$ & Challenging job requirement & 0.208 & 0.054 & 3.824 & $* * *$ \\
\hline Job performance & $<->$ & Social job resources & 0.237 & 0.045 & 5.295 & $* * *$ \\
\hline Job performance & $\langle->$ & Challenging job requirement & 0.043 & 0.036 & 1.202 & 0.229 \\
\hline Job performance & $\langle->$ & Structural job resources & 0.132 & 0.043 & 3.078 & 0.002 \\
\hline Job performance & $\langle->$ & Proactive personality & 0.192 & 0.043 & 4.511 & $* * *$ \\
\hline Social job resources & $\langle-->$ & Structural job resources & 0.236 & 0.055 & 4.306 & $* * *$ \\
\hline
\end{tabular}

\subsection{Structural Equation Model Analysis}

The structural equation model allows the measurement of the measurement errors through surpluses and the integration of researching concepts that are hard to measure and abstract (Hair et al., 2006; Kline, 2011). The SEM model is analyzed by partial subgroup method (Bagozzi and Edwards, 1998) by creating the observational variable packages proposed by Hall et al. (1999). An observational variable package can be defined as a variable consisting of an average of two or more other observational variables. The advantage of collecting group of observational variables is to create more reliable measurement models (Little et al., 2012). Collecting group of observational variables helps reduce the probability of incorrect model estimation, has fewer convergence times, and results in more stable solutions. Research creates observational variable packages for the concept of the proactive personality, job crafting and job performance.

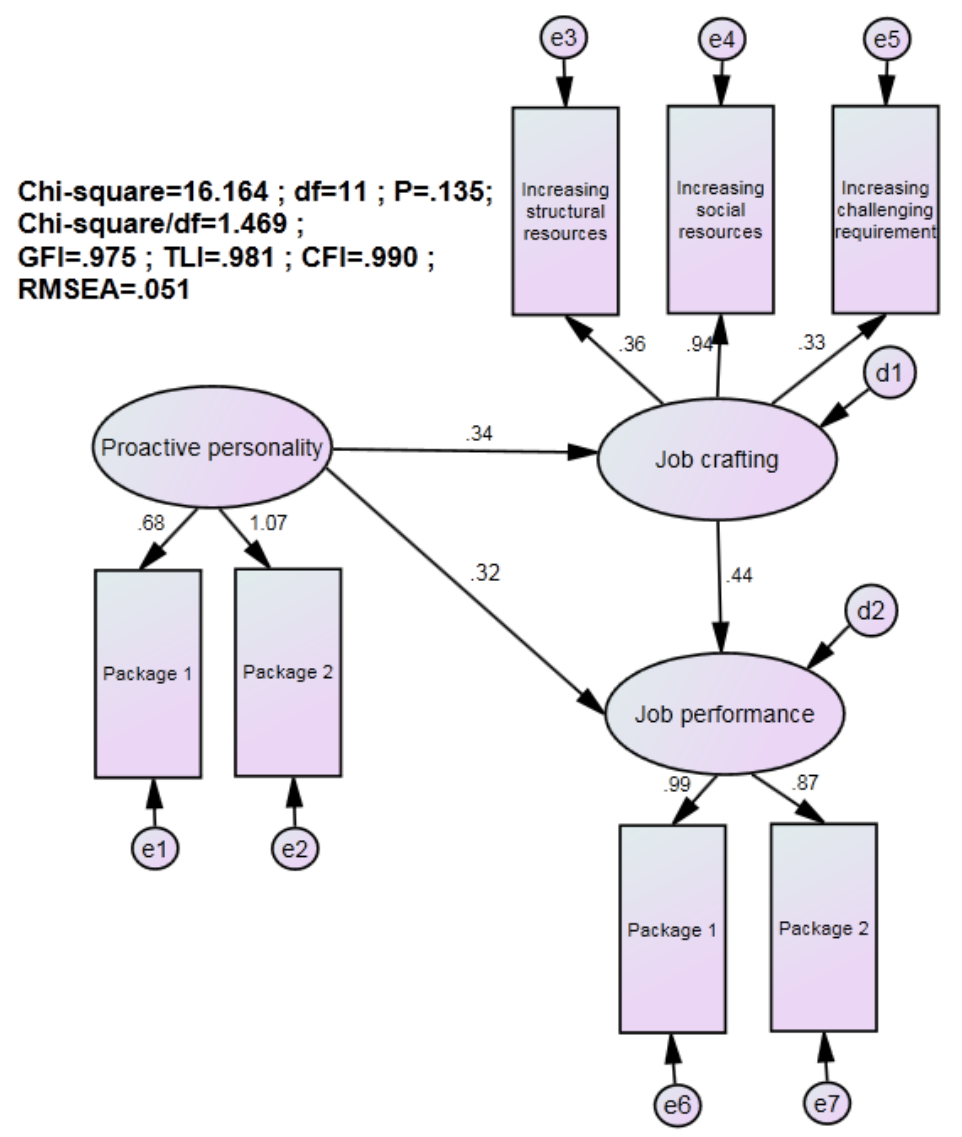

Figure 3. SEM model result 
The results of the SEM analysis from the study data (Figure 3) showed that Chi-square/df = 1.469 is less than $2, \mathrm{GFI}=0.975$ is greater than 0.9 , TLI $=0.981$ and $\mathrm{CFI}=0.990$ is greater than 0.9 , RMSEA $=0.051$ is less than 0.08 . This proves that the analytical model is consistent with the market data.

Table 3. Estimated results of the cause-and-effect relationship between the concepts in the research model

\begin{tabular}{|l|c|l|c|c|c|c|}
\hline \multicolumn{2}{|c|}{ Relationship between the concepts } & Estimated & S.E. & C.R. & P \\
\hline Job crafting & $<--$ & Proactive personality & 0.149 & 0.054 & 2.769 & 0.006 \\
\hline Job performance & $<---$ & Proactive personality & 0.435 & 0.098 & 4.452 & $* * *$ \\
\hline Job performance & $<---$ & Job crafting & 1.354 & 0.373 & 3.628 & $* * *$ \\
\hline
\end{tabular}

The main parameter estimation results (Table 3) show that the relationship between proactivity personality, job crafting and job performance is a statistical significance $(\mathrm{p}<$ $0.05)$.

Based on the weighted regression results between the concepts, proactivity personality strongly influenced with the same direction of job crafting with a weight of 0.34 . Thus, the hypothesis 1 (H1) is accepted: proactivity personality has a positive effect on job crafting (increasing structural job resources, increasing social job resources, increasing job challenges).

The results show that the components of job crafting have a positive effect on job performance with a weight of 0.44 . Thus, the hypothesis $2(\mathrm{H} 2)$ is accepted: job crafting (increasing structural job resources, increasing social job resources, increasing challenging job requirements) has a positive effect on job performance.

At the same time, the results show that the proactivity personality positively influences the job performance with a coefficient of 0.32 . Therefore, proactivity directly affects the performance of employees. Thus, hypothesis $3(\mathrm{H} 3)$ is accepted: proactivity personality has a positive effect on job performance.

From the positive impact of proactivity personality on job crafting and the positive impact of job crafting on job performance. Thus, it can be assured that proactivity personality has a positive impact indirectly on job performance through job crafting.

\subsection{Analysis from Research Results}

First, the research results provided an evidence to reinforce the hypothesis on proactivity personality of the employee has a positive impact on job crafting and job performance. Individuals with proactivity personality tend to change their surrounding environment deliberately (Buss, 1987). They identify opportunities, actions and persistence until significant changes occur (Crant, 1995). This research extends previous researches by pointing out that individuals with proactivity personality almost tend to change their working environment proactively by transforming their job resources and job requirements. This is also true to Crant's study (2000) showing that proactivity personality has a positive impact on job performance of the employee because individuals create proactively more opportunities 
to achieve efficiency. Job crafting has a direct impact on job performance because employees change their working environment while appropriately adjusting job resources and job requirements in line with ability and their own requirements (Tim and Bakker, 2010). A suitable human-environmental theory has confirmed that employees leave the organization when on the one hand there is no compatibility of their demands and abilities, on the other hand, there is no compatibility of organization's requirements and resources. (Edwards, 2008; Schneider et al., 1997). This research shows that if employees cannot or do not want to leave the organization, they can perform job crafting as a way to find convergence between human and the working environment. Research results show that proactivity personality influencing job performance through job crafting is similar to that of Daniel (2006). Daniel's research (2006) shows that general personality is the most important predictor of organization's job performance. Individuals with proactivity personality do not really have a good job performance unless they are associated with job crafting.

Second, the research results show the relationship between the components of job crafting and job performance. This research shows that employees optimize work requirements for them to be more challenging, and those who increase their structural job resources and social job resources have better job performance than those who do not. The theory of job crafting has been very cautious about the research results of job crafting that affect job performance. As Wrzesniewski and Dutton (2001) confirms that job crafting is not necessarily aligned with organization's goals. However, Lyons (2008) points out that all the examples used to describe job crafting also have a positive impact on the organization. This study also supports the positive correlation between job crafting behavior and job performance.

Third, the research results show that proactive personality is an important predictor of job performance. This shows that the choice of individuals with proactive personality can be the useful human resource strategy for managers seeking to improve their job performance. However, the study agrees with Fuller et al. (2010) that optimized performance is not the only option for individuals with proactive personality, but also a matter of assigning the individuals the tasks they feel they have the discretion to determine how they perform their job. At the level of managing organization, the leader should create a good working environment that encourages employees to participate in the work (Bakker et al., 2011). A working environment supports and challenges the employees and concurrently meets the demands of making employees more willing to invest their time and energy at the workplace. Starting from the job demands-resources model (JD-R), the organization can create personal resources and employee's job (Bakker and Demerouti, 2008). For example, providing labor has the opportunity to develop their skills and abilities, and can increase their involvement because they can develop themselves at work and can join in new challenging task.

\section{Conclusion and Proposal}

\subsection{Conclusion}

Research results provide evidence for the ability of proactive personality to positively influence the job performance in a direct and indirect way. This is also true of theory on proactive personality of Buss (1987), Crant (1995), Bakker et al. (2012). This study also 
shows the positive relationship between job crafting and job performance. Employees who increase their structural job resources, and social job resources have a better job performance than those who do not increase their job requirements and job resources. Structural job resources encourage job cohesion that has a positive impact on organization's job performance. Hence, increasing job resources will lead to increasing individual's outcomes, such as job satisfaction and job performance. In terms of the increase in social job resources mention social support, supervisory training, and feedback from managers and colleagues, the increase in social job resources have a greater impact on the social job aspect and achieve the satisfaction level of interaction.

\subsection{Proposal}

This study suggests some of the management implication proposals for administrator to the employees in the banking and finance sector in general and at Vietcombank in Ho Chi Minh City in particular. The research provides ideas for selecting and recruiting human resources, maintaining a working environment, and managing job performance.

First, the study proposes that the search, selection, and recruitment of employee with proactive personality bring a lot of benefits. A person with proactive personality always has the sense of their obtimal job crafting. They always seek a way to increase the structural job resources and challenging job requirements. They perform a good job and take part in job with all their resources. This has a positive impact on the organization's performance and positive environment. For example, employers need to design recruitment that focuses on assessing the candidate's proactive personality, ready to change to adapt to the working environment.

Second, maintaining the organization's working environment in a way that encourages proactive personality and job crafting is likely to have positive effects. Employees working in the organization's positive environment tend to increase social job resources, improve and maintain good relationships with colleagues, thereby contributing to improve the organization's job performance. For example, managers need to empower employees more in decision-making, listening and encouraging employees to contribute new ideas, creating opportunities for employees to develop their vocational and specialized skills.

Third, in the term of an organization's performance management, the administrator should not only focus on creating a positive working environment, but also focus on reducing the overloading work requirement for employees. This helps to balance the work requirements and resources for performing the employee's job. For example, administrator needs to rely on the ability of their employees to assign appropriate tasks, and each task requires a specific and appropriate job description and job standard.

\section{References}

Baba, V. V., Tourigny, L., Wang, X., \& Liu, W. (2009). Proactive Personality and Work Performance in China: The Moderating Effects of Emotional Exhaustion and Perceived Safety Climate. Canadian Journal of Administrative Sciences, 26, 23-37.

https://doi.org/10.1002/cjas.90 
Bagozzi, R. P., \& Edwards, J. R. (1998). A general approach for representing constructs in organizational research. Organizational research methods, 1(1), 45-87.

https://doi.org/10.1177/109442819800100104

Bakker, A. B., \& Demerouti, E. (2007). The job demands-resources model: State of the art. Journal of Managerial Psychology, 22, 309-328. https://doi.org/10.1108/02683940710733115

Bakker, A. B., Demerouti, E., \& Xanthopoulou, D. (2012). How do engaged employees stay engaged?. Ciencia \& Trabajo, 14(special issue), 16-22.

Bakker, A. B., Tims, M., \& Derks, D. (2012). Proactive Personality and Job Performance: The role of Job Crafting and Job Engagement. Human Relations, 65(10), 1359-1378. https://doi.org/10.1177/0018726712453471

Bateman, T. S. \& Crant, M. J. (1993). The proactive component of organizational behavior: A measure and correlates summary. Journal of Organizational Behavior, 14, 103-119. https://doi.org/10.1002/job.4030140202

Becherer, R. C., \& Maurer, J. G. (1999). The proactive personality disposition and entrepreneurial behavior among small company presidents. Journal of small business management, 37(1), 28.

Berg, J. M., Dutton, J. E., \& Wrzesniewski, A. (2008). What is job crafting and why does it matter?. Center for Positive Organizational Scholarship, University of Michigan Theory-to-Practice Briefing, 1-8.

Berg, J. M., Wrzesniewski, A., \& Dutton, J. E. (2010). Perceiving and responding to challenges in job crafting at different ranks: When proactivity requires adaptivity. Journal of Organizational Behavior, 31, 158-186. https://doi.org/10.1002/job.645

Buss, D. M. (1987). Selection, evocation, and manipulation. Journal of Personality and Social Psychology, 53, 1214-1221. https://doi.org/10.1037/0022-3514.53.6.1214

Crant, J. M. (1995). The proactive personality scale and objective job performance among real estate agents. Journal of Applied Psychology, 80, 532-537.

https://doi.org/10.1037/0021-9010.80.4.532

Crant, J. M. (1996). The proactive personality scale as a predictor of entrepreneurial intentions. Journal of small business management, 34, 42-49.

Crant, J. M. (2000). Proactive behavior in organizations. Journal of Management, 26, 435-462. https://doi.org/10.1177/014920630002600304

Crant, J. M., \& Bateman, T. S. (2000). Charismatic leadership viewed from above: The impact of proactive personality. Journal of organizational Behavior,21(1), 63-75. https://doi.org/10.1002/(SICI)1099-1379(200002)21:1<63::AID-JOB8>3.0.CO;2-J

Daniels K (2006) Rethinking job characteristics in work stress research. Human Relations, 59, 267-290. https://doi.org/10.1177/0018726706064171 
Deluga, R. J. (1998). American presidential proactivity, charismatic leadership, and rated performance. The Leadership Quarterly, 9(3), 265-291.

https://doi.org/10.1016/S1048-9843(98)90030-3

Edwards, J. R. (2008). Person-environment fit in organizations: An assessment of theoretical progress. The Academy of Management Annals, 2, 167-230.

https://doi.org/10.5465/19416520802211503

Fuller, J. B., Hester, K., \& Cox, S. (2010). Proactive personality and job performance: Exploring job autonomy as a moderator. Journal of Managerial Issues, 22, 35-51.

Greguras, G. J., \& Diefendorff, J. M. (2010). Why does proactive personality predict employee life satisfaction and work behaviors? A field investigation of the mediating role of the self-concordance model. Personnel Psychology, 63, 539-560.

https://doi.org/10.1111/j.1744-6570.2010.01180.x

Hair, J. F., Black, W. C., Babin, B. J., Anderson, R. E., \& Tatham, R. L. (2006). Multivariate data analysis (Vol. 6).

Hall, R. J., Snell, A. F., \& Foust, M. (1999). Item parceling strategies in SEM: Investigating the subtle effects of unmodeled secondary constructs. Organizational Research Methods, 2, 233-256. https://doi.org/10.1177/109442819923002

Kirkman, B. L., \& Rosen, B. (1999). Beyond self-management: Antecedents and consequences of team empowerment. Academy of Management journal, 42(1), 58-74.

Kline, R. B. (1998). Principles and practice of structural equation modeling. New York: Guilford Press.

Little, T. D., Bovaird, J. A., \& Card, N. A. (Eds.). (2012). Modeling contextual effects in longitudinal studies. Routledge.

Lyons, P. (2008). The crafting of jobs and individual differences. Journal of Business Psychology, 23, 25-36. https://doi.org/10.1007/s10869-008-9080-2

Ohly, S., Sonnentag, S., Niessen, C., \& Zapf, D. (2010). Diary studies in organizational research: An introduction and some practical recommendations. Journal of Personnel Psychology, 9, 79-93. https://doi.org/10.1027/1866-5888/a000009

Parker, S. K. (1998). Enhancing role breadth self-efficacy: the roles of job enrichment and other organizational interventions. Journal of applied psychology, 83(6), 835.

https://doi.org/10.1037/0021-9010.83.6.835

Saetang, J., Sulumnad, K., Thampitak, P., \& Sungkaew, T. (2010). Factors affecting perceived job performance among staff: A case study of Ban Karuna Juvenile Vocational Training Centre for boys. International Journal of Behavioral Science, 5(1), 33-45.

Seibert, S. E., Crant, J. M., \& Kraimer, M. L. (1999). Proactive personality and career success. Journal of applied psychology, 84(3), 416. https://doi.org/10.1037/0021-9010.84.3.416 


\section{Macrothink}

Business and Economic Research

ISSN 2162-4860

2018, Vol. 8, No. 3

Schneider, B., Kristof, A. L., Goldstein, H. W., \& Smith, D. B. (1997). What is this thing called fit? In: Anderson NR and Herriott P (eds) Handbook of Selection and Appraisal, 2nd edn. London: Wiley, 393-412

Thompson, J. A. (2005). Proactive Personality and Job Performance: A Social Capital Perspective. Journal of Applied Psychology, 90(5), 1011-1017.

https://doi.org/10.1037/0021-9010.90.5.1011

Tims, M., \& Bakker, A. B. (2010). Job crafting: Towards a new model of individual job redesign. South African Journal of Industrial Psychology, 36, 1-9.

https://doi.org/10.4102/sajip.v36i2.841

Tims, M., Bakker, A. B., \& Derks, D. (2012). Development and Validation of the Job Crafting Scale. Journal of Vocational Behavior, 80, 173-186. https://doi.org/10.1016/j.jvb.2011.05.009

Williams, L. J., \& Anderson, S. E. (1991). Job satisfaction and organizational commitment as predictors of organizational citizenship and in-role behaviors. Journal of management, 17(3), 601-617. https://doi.org/10.1177/014920639101700305

Wrzesniewski, A., \& Dutton, J. E. (2001). Crafting a job: Revisioning employees as active crafters of their work. Academy of Management Review, 26(2), 179-201.

https://doi.org/10.5465/amr.2001.4378011

\section{Copyright Disclaimer}

Copyright for this article is retained by the author(s), with first publication rights granted to the journal.

This is an open-access article distributed under the terms and conditions of the Creative Commons Attribution license (http://creativecommons.org/licenses/by/3.0/). 